\title{
EFEKTIVITAS PENGELOLAAN ANGGARAN PENDAPATAN DAN BELANJA DESA DI DESA SELAAWI KECAMATAN TALEGONG KABUPATEN GARUT
}

\author{
Widdy Yuspita Widiyaningrum ${ }^{1}$, Wiguna ${ }^{2}$ \\ ${ }^{1}$ Program Studi Ilmu Pemerintahan, Universitas Bale Bandung, Jawa Barat Indonesia \\ Email: widdyyuspita80@gmail.com \\ ${ }^{2}$ Pemerintahan Desa Selaawi, Kecamatan Talegong, Kabupaten Garut, Indonesia \\ Email: wiguna8933@gmail.com
}

\begin{abstract}
ABSTRAK
Anggaran Pendapatan dan Belanja Desa adalah rencana keuangan tahunan pemerintah desa yang dibahas dan disetujui bersama oleh pemerintah desa dan Badan Permusyawaratan Desa rancangan anggaran pendapatan dan belanja desa dibahas dalam musyawarah perencanaan pembangunan desa. Dengan adanya pandemi covid-19 berbagai kebijakan dibuat untuk mempercepat penanggulangan penyebaran covid-19 hingga ke tingkat desa pemerintah menerbitkan Permendes Nomor 7 Tahun 2020 Perubahan Kedua yang mengatur mengenai perubahan prioritas dana desa untuk: Penanggulangan Covid-19, Padat karya tunai desa, Bantuan langsung tunai. Tujuan dari penelitian ini adalah untuk mengetahui dan memahami efektivitas program tersebut dengan mengunakan teori Martani dan Lubis (1987) melalui tiga pendekatan yang pertama Pendekatan Sumber kedua Pendekatan Proses dan yang ketiga Pendekatan Sasaran. Metode yang digunakan dalam penelitian ini adalah kualitatif dengan pendekatan deskriptif analisis. Pengumpulan data dilakukan dengan observasi, wawancara dan dokumentasi. Dalam proses pengumpulan data peneliti melibatkan beberapa pengurus Perangkat Desa yang menjadi objek penelitian kemudian data yang telah diperoleh diolah dan dianalisis setelah itu diinterprestasikan. Hasil dari penelitian ini menunjukkan bahwa desa sudah menerapkan penggunaan anggaran tahun 2020 yakni pencegahan dan penanganan covid-19, Padat karya tunai dan Bantuan langsung tunai dengan merubah/mengeser anggaran pembangunan. Efektivitas serapan anggaran yang diperoleh dari hasil penelitian ini menunjukkan tingkat pencapaian kinerja Pemerintah Desa dalam Pencegahan dan penanganan covid-19, Padat karya tunai dan Bantuan langsung tunai Pemerintah Desa telah menerapkan tingkat keefektifan walaupun belum sempurna. Pengelolaan Anggaran Pendapatan dan Belanja Desa harus lebih efektif perlu adanya peningkatan kualitas sumber daya manusia aparatur desa khususnya kepala desa, kepala urusan keuangan desa dan tim pelaksana kegiatan serta menyampaikan aspirasi pemerintah desa ke pemerintah pusat.
\end{abstract}

Kata Kunci: Efektivitas; Pengelolaan Anggaran Desa; APBDes.

\begin{abstract}
The Village Fundling's (pengelolaan Anggaran Desa) is the government's annual financial plan that was discussed and jointly approved by the village government and the village's high assembly (badan permusyawaratan desa) for the draft revenue and spending budget discussed on village development planning deliberations. In case the covid-19 pandemic, various policies were made to accelerate the response to recovering from
\end{abstract}


covid-19, to the village level the government issued Permendes No. 7 of 2020 Perubahan Kedua which regulates changes in village fund priorities for: Covid-19 Countermeasures, Village cash-intensive, direct assistance for direct funds (bantuan langsung tunai). This paper is going to find out and understand the effectiveness of the program by using martani and lubis theory (1987) through the three approaches: first source approach, then the process and last the target approach. The method used in this study is qualitative with a descriptive approach to analyze. Data is collecting by observations, interviews some participant (the villages employee) and documentation. In the process of collecting data, researchers involve several village's administrators who becomes the object of research, then data which has been obtained is processed and analyzed after it is interpreted. The results are showed that the village has implemented the 2020 budget use for prevention and handling the side effect of covid-19, cash-intensive and direct cash assistance by changing / adjusting the development budget. The effectiveness of budget uptake obtained from the results of this study shows the level of achievement of village government performance in the prevention and handling of covid-19, cash-intensive and direct cash assistance of the village's government has implemented a level of effectiveness although that's not perfectly at all. The management of the Village Revenue and direct funds (bantuan langsung tunai) must be more effective in the need to improve the quality of human resources of the village apparatus, especially the village head, the head of village financial affairs and the implementation team of activities and convey the aspirations of the village government to the central government.

Keywords: Effectiveness; Village Budget Management; APBDes.

\section{Informasi Artikel}

Diterima: Oktober 2021, Disetujui: November 2021, Dipublikasikan: Desember 2021

DOI: https://doi.org/10.47431/governabilitas.v2i2.118

\section{PENDAHULUAN}

Berdasarkan Undang-Undang Nomor 6 Tahun 2014 Desa adalah kesatuan masyarakat hukum yang mempunyai batas wilayah yang berwenang guna mengatur serta mengurus urusan pemerintahan, kepentingan masyarakat setempat sesuai dengan prakarsa masyarakat, hak asal usul serta hak tradisional yang diakui dan dihormati pada sistem pemerintahan Negara Kesatuan Republik Indonesia. Undang-undang tersebut negara menjamin tanggung jawab untuk melindungi dan memberdayakan desa agar menjadi desa yang memiliki landasan kuat guna mewujudkan roda pemerintahan serta pembangunan desa dan masyarakat yang sejahtera (Laksmi, 2015). Kemudian desa di harapkan mampu membentuk desa dimana: Desa tidak hanya menjadi objek penerima manfaat melainkan desa menjadi subjek pemberi manfaat bagi warga masyarakat setempat. Menjadi salah satu komponen desa memiliki jiwa gotong royong guna meningkatkan aset desa sebagai sumber pencaharian masyarakat. Desa memiliki 
kemampuan guna menghasilkan dan mencukupi kebutuhan serta keperluan masyarakat setempat (Pradana, 2021).

Untuk mewujudkan tujuan tersebut dibutuhkan penyelenggaraan pemerintah desa yang baik yang memenuhi prinsip Good Governence yaitu partisipatif, transparan, dan akuntabel (Pradana, 2021). Salah satu instrument yang menjadi tolok-ukur dalam tata kelola pemerintahan desa yang baik adalah good governance berupa anggaran. Dalam pengelolaan keuangan desa dibekali dengan pedoman pengelolaan keuangan desa dalam Permendagri Nomor 20 Tahun 2018 yang menjelaskan bahwa pengelolaan keuangan desa adalah keseluruhan kegiatan yang meliputi perencanaan, pelaksanaan, penatausahaan, pelaporan dan pertanggungjawaban keuangan desa. Proses pengelolaan harus memperhatikan antara input, output dan outcome yang dihasilkan perencanaan jangka Panjang serta keterlibatan masyarakat dalam proses penganggaran tersebut.

Undang-Undang desa telah memastikan desa berada digaris depan pembangunan dan peningkatan kesejahteraan masyarakat. Untuk mewujudkan tujuan tersebut pemerintah desa patut mengambil langkah terkait kebijakan pemerintah pusat yang telah menggelontorkan dana desa sebagai stimulus pembangunan desa secara adil dan merata. Menurut Undang-Undang Nomor 6 Tahun 2014 Dana Desa merupakan dana yang bersumber dari Anggaran Pendapatan dan Belanja Negara (APBN) yang diperuntukkan bagi desa dan di salurkan melalui Anggaran Pendapatan dan Belanja Daerah (APBD) kabupaten/kota serta digunakan dalam membiayai penyelenggaraan roda pemerintahan, pembangunan dan pemberdayaan masyarakat.

Pengelolaan keuangan desa agar dana yang jumlahnya sangat terbatas dapat dipergunakan secara efektif, efisien, ekonomis dan berkeadilan (Halim, 2007). Secara efektif maksudnya bahwa pengelolaan keuangan desa tersebut harus dapat mencapai tujuan atau sasaran yang ingin di capai (Chabib Soleh dan Heru Rochmansjah, 2014). Dalam Permendagri Nomor 20 Tahun 2018 Tentang Pengelolaan Keuangan Desa merupakan Rencana keuangan tahunan pemerintah desa yang dibahas dan disetujui bersama oleh pemerintah desa dan badan permusyawaratan desa yang ditetapkan dengan peraturan desa yang terdiri dari Pendapatan, Belanja dan Pembiayaan.

Anggaran Pendapatan dan Belanja Desa (APBDes) merupakan rencana keuangan tahunan desa. Penyusunan APBDes disusun berdasarkan prinsip partisipatif, transparan dan akuntabel. Anggaran tidak hanya dipandang dari sisi tataran teknis peraturan perundangan semata karena aspek anggaran tidak terlepas dari faktor manusia yang memiliki peranan penting di dalam proses penganggaran (Pradana, 2020). 
Pada tahun anggaran 2020 terdapat perubahan anggaran dana desa untuk seluruh desa di Kabupaten Garut. Pemerintah Desa Selaawi Kecamatan Talegong Kabupaten Garut menerima anggaran dana desa tahun anggaran 2020 sesuai dengan Perdes Nomor 9 tahun 2020 mengenai perubahan kedua atas Perdes Nomor 6 Tahun 2019 tentang anggaran pendapatan dan belanja desa yang sebelumnya sebesar Rp. 1.948.070.913, berubah menjadi Rp. 1.962.688.948, - dengan rincian pendapatan sebagai berikut:

Tabel 1. Anggaran Pendapatan Desa Selaawi Kecamatan Talegong Kabupaten Garut

\begin{tabular}{|c|c|c|c|c|c|}
\hline \multirow[b]{2}{*}{ No } & \multirow[b]{2}{*}{ Uraian } & \multicolumn{2}{|c|}{ Anggaran Rp } & \multirow{2}{*}{$\begin{array}{l}\text { Bertambah } \\
\text { /Berkurang }\end{array}$} & \multirow{2}{*}{$\begin{array}{c}\text { Persen } \\
(\%)\end{array}$} \\
\hline & & Semula & Menjadi & & \\
\hline 1. & Pendapatan Asli Desa & 8.300 .000 & 8.100 .000 & $(200.000)$ & $98 \%$ \\
\hline 2. & Dana Desa & 1.210 .721 .000 & 1.199 .914 .000 & $(10.807 .000)$ & $99 \%$ \\
\hline 3. & $\begin{array}{l}\text { Bagi Hasil Pajak dan } \\
\text { Retrebusi }\end{array}$ & 36.371 .981 & 41.479 .100 & 5.107 .119 & $14 \%$ \\
\hline 4. & Alokasi Dana Desa & 560.581 .640 & 530.879 .557 & $(29.702 .083)$ & $95 \%$ \\
\hline 5. & $\begin{array}{l}\text { Bantuan Keuangan } \\
\text { Provinsi }\end{array}$ & 130.000 .000 & 130.000 .000 & 0 & $100 \%$ \\
\hline 6. & $\begin{array}{l}\text { Bantuan Keuangan } \\
\text { Kabupaten Kota }\end{array}$ & 0 & 40.000 .000 & 40.000 .000 & - \\
\hline 7. & Pendapatan lain-lain & 2.096 .292 & 12.316 .292 & 10.220 .000 & $58 \%$ \\
\hline & JUMLAH & 1.948.070.913 & 1.962.688.948 & 14.618.036 & \\
\hline
\end{tabular}

Sumber: Data dari APBDes Perubahan Desa Selaawi Kec. Talegong Kab. Garut tahun 2020 (data diolah)

Peraturan Menteri Desa, Pembangunan Daerah Tertinggal dan Transmigrasi Nomor 11 Tahun 2019 tentang Prioritas Penggunaan Dana Desa disebutkan mengenai alokasi dana desa pada tahun 2020 harus memberikan manfaat perubahaan yang besar serta berdampak langsung bagi pengembangan kualitas hidup dan kesejahteraan masyarakat pengendalian kemiskinan serta peningkatan pelayanan publik.

Pasca ditetapkannya Covid-19 sudah menyebabkan pandemi global yang berdampak terhadap segala aspek kehidupan masyarakat. Efek yang ditimbulkan dari pandemi Covid-19 yang besar terutama pada bidang kesehatan, sosial dan ekonomi mewajibkan pemerintah membuat kebijakan dengan menyesuaikan situasi dan kondisi darurat yang sedang terjadi yang mengakibatkan kelumpuhan di setiap lini yang mengharuskan pemerintah untuk menggeserkan alokasi dana (Adisasmita, 2011).

Adanya pandemi Covid-19 berbagai kebijakan dibuat untuk mempercepat penanggulangan penyebaran Covid-19 hingga ke tingkat desa pemerintah yang semula menterbitkan Permendes Nomor 11 Tahun 2019 Tentang Prioritas Penggunaan Dana Desa yang tidak dijelaskan pemanfaatan dana desa untuk penanggulangan Covid-19 harus diubah menyesuaikan dengan kondisi yang terjadi dengan menerbitkan Permendes 
Nomor 7 Tahun 2020 Perubahan Kedua yang mengatur mengenai perubahan prioritas dana desa untuk:

1. Penanggulangan Covid-19.

2. Padat Karya Tunai Desa

3. Bantuan Langsung Tunai

Meskipun Desa Selaawi Kecamatan Talegong menjadi salah satu wilayah dengan zona hijau tetapi hal ini justru yang membuat pemerintah daerah setempat untuk melakukan peningkatan kewaspadaan sedari dini maka pengelolaan APBDes tahun 2020 di Desa Selaawi yang semula sudah direncanakan dan disusun mengalami perubahan dan diprioritaskan untuk Penanganan Covid-19, Padat Karya Tunai (PKT) dan Bantuan Langsung Tunai.

Kebijakan penganggaran dengan menggunakan pendekatan Refocusing anggaran dalam penanganan Covid-19 pada pemerintahan desa tentunya harus menggunakan pendekatan kehati-hatian. Hal ini melihat dari konsekuensi terbengkalainya penganggaran sebelumnya yang pastinya terabaikan dengan adanya penganggaran yang baru dampak yang jelas-jelas terbukti adalah dengan terbengkalainya kebijakan yang dijalankan sebelumnya dalam penyelenggaraan pemerintahan dibidang infrastruktur (Dunn, 2005). Ketika keadaan infrastruktur di sebuah desa lemah perekonomian desa berjalan dengan cara yang kurang efisien yang menyebabkan biaya logistik yang sangat tinggi berujung pada perusahaan dan bisnis yang kekurangan daya saing karena biaya bisnis yang tinggi, sulit bagi sebagian penduduk untuk berkunjung ke fasilitas kesehatan karena fasilitas kesehatan yang kurang memadai dan perjalanannya terlalu susah. Berikut tabel Penggunaan Anggaran untuk Penanganan Covid-19, Padat Karya Tunai, dan Bantuan Langsung Tunai:

Tabel 2. Anggaran Penanganan Covid-19

\begin{tabular}{|c|l|c|c|}
\hline No & \multicolumn{1}{|c|}{ Uraian } & Jumlah & Sumber Dana \\
\hline 1. & $\begin{array}{l}\text { Sterilisasi fasilitas umum dan fasilitas sosial } \\
\text { Desa }\end{array}$ & 8.519 .000 & Dana Desa \\
\hline 2. & $\begin{array}{l}\text { Sterilisasi, Pengadaan Bahan/kesehatan, } \\
\text { CTPS, Sosialisasi }\end{array}$ & 98.100 .000 & Banprov \\
\hline 3. & Gerakan Seribu Masker 4.200 buah x 5.000 & 21.000 .000 & Dana Desa \\
\hline \multicolumn{2}{|c|}{ JUMLAH TOTAL } & $\mathbf{1 2 7 . 6 1 9 . 0 0 0}$ & \\
\hline
\end{tabular}

Sumber: Data dari APBDes Perubahan Desa Selaawi, Tahun 2020 (data diolah)

Namun dalam keberlangsungannya langkah pemerintah desa dalam penanganan covid-19 masih kurang efektif hal itu terlihat beberapa masyarakat desa Selaawi masih 
belum mengerti langkah-langkah apa yang harus dilakukan untuk menghambat penyebaran virus-19 ini. Dijumpai bahwa orang-orang tidak mengindahkan larangan pemerintah agar melakukan social distancing dan physical distancing (tidak berkerumun) di sejumlah tempata juga dijumpai masyarakat yang tidak memakai masker dan enggan mencuci tangan dengan sabun atau cairan disinfektan.

Tabel 3. Anggaran Padat Karya Tunai Desa

\begin{tabular}{|c|c|c|c|c|}
\hline No & Uraian & Satuan & Jumlah & Sumber Dana \\
\hline A. & \multicolumn{2}{|c|}{ Padat Karya Tunai Desa } & $\mathbf{4 8 . 6 2 5 . 0 0 0}$ & \multirow{2}{*}{ Dana Desa } \\
\hline 1. & Pembukaan Jalan Baru & 288 Meter & 48.625 .000 & \\
\hline \multicolumn{3}{|l|}{ JUMLAH TOTAL } & $\mathbf{4 8 . 6 2 5 . 0 0 0}$ & \\
\hline
\end{tabular}

Sumber: Data dari APBDes Perubahan Desa Selaawi, Tahun 2020 (data diolah)

Menurut Peraturan Menteri Desa Pembangunan Daerah Tertinggal dan Transmigrasi Nomor 7 Tahun 2020 Perubahan Kedua tentang Prioritas Penggunaan Dana Desa Tahun 2020, Padat Karya Tunai adalah kegiatan pemberdayaan masyarakat desa khususnya yang miskin dan marginal yang bersifat produktif dengan mengutamakan pemanfaatan sumber daya tenaga kerja dan teknologi lokal untuk memberikan tambahan upah/pendapatan, mengurangi kemiskinan dan meningkatkan kesejahteraan rakyat. Kegiatan berupa pembangunan infrastruktur seperti pembangunan jalan masih kurang efektif bagi penduduk miskin yang terlibat dalam proyek tersebut, sebagai tenaga kuli harian sesungguhnya manfaatnya sangatlah temporer bahkan nyaris tidak berbekas.

Tabel 4. Anggaran Bantuan Langsung Tunai dan Sembako

\begin{tabular}{|c|c|c|c|c|c|}
\hline No & Uraian & Satuan & $\begin{array}{l}\text { Harga } \\
\text { Satua }\end{array}$ & Jumlah & $\begin{array}{c}\text { Sumber } \\
\text { Dana }\end{array}$ \\
\hline A. & \multicolumn{3}{|c|}{ Bantuan Langsung Tunai (BLT DD) } & 504.000 .000 & \multirow[b]{3}{*}{$\begin{array}{l}\text { Dana } \\
\text { Desa }\end{array}$} \\
\hline 1. & BLT DD April s/d Juni & $140 \mathrm{KPM}$ & 600.000 & 252.000 .000 & \\
\hline 2. & BLT DD Juli s/d Desember & $140 \mathrm{KPM}$ & 300.000 & 252.000 .000 & \\
\hline B. & \multicolumn{3}{|l|}{ Bantuan Pangan (Sembako) } & 80.000 .000 & \multirow{4}{*}{ ADD } \\
\hline 1. & Beras $5 \mathrm{~kg}$ & $1.000 \mathrm{KK}$ & 13.000 & 65.000 .000 & \\
\hline 2. & Minyak Goreng 1 liter & $1.000 \mathrm{KK}$ & 15.000 & 15.000 .000 & \\
\hline \multicolumn{4}{|c|}{ JUMLAH TOTAL } & 584.000 .000 & \\
\hline
\end{tabular}

Sumber: Data dari APBDes Perubahan Desa Selaawi, Tahun 2020 (data diolah)

Menurut Permendes Nomor 7 tahun 2020 kriteria calon keluarga yang berhak menerima BLT desa adalah keluarga miskin atau tidak mampu yang berdomisili di desa bersangkutan. Selain itu harus dipastikan bahwa calon penerima bansos ini tidak termasuk ke dalam penerima bantuan Program Keluarga Harapan (PKH), Kartu Sembako dan Kartu Prakerja. Pendataan calon penerima BLT desa akan mempertimbangkan Data Terpadu Kesejahteraan Sosial (DTKS) dari Kementerian Sosial (Kemensos). Secara 
umum kemiskinan adalah bilamana masyarakat berada pada suatu kondisi yang serba terbatas baik dalam aksesibilitas pada faktor produksi, peluang/kesempatan berusaha, pendidikan, fasilitas hidup lainnya (Akhir, 2012). Program Bantuan Langsung Tunai (BLT) di latarbelakangi upaya mempertahankan tingkat konsumsi Rumah Tangga Sasaran (RTS) sebagai akibat adanya pandemi yang berdampak akan perekonomian masyarakat terutama masyarakat miskin yng terkena dampak (Fernando, 2020).

Keberlangsungan bantuan langsung tunai masih kurang efektif adanya penerima dana bantuan yang sebenarnya tidak layak menerima namun menerima juga sebaliknya ada yang terlihat layak namun tidak menerima data penerima yang tidak akurat dan manfaatnya uangnya kurang bermanfaat. Berikut tabel daftar Penerima Bantuan Langsung Tunai Desa Selaawi yang menurut peneliti tidak layak menerima:

Tabel 5. Daftar Penerima BLT DD Desa Selaawi Tahun 2020

\begin{tabular}{|c|l|l|l|l|}
\hline No & Nama Penerima & \multicolumn{1}{|c|}{ NIK } & \multicolumn{1}{|c|}{$\begin{array}{c}\text { Tanggal } \\
\text { Lahir }\end{array}$} & \multicolumn{1}{|c|}{ Alamat Lengkap } \\
\hline 1 & Yayan Henrdawan & 3205372005950002 & $20-05-1994$ & Kp.Selaawi 001/001 \\
\hline 2 & Imat & 3205370610950003 & $06-12-1993$ & Kp.Selaawi 3 004/002 \\
\hline 3 & Mamat & 3205370802500001 & $08-02-1950$ & Kp.Selaawi 3 004/002 \\
\hline 4 & Dani & 3205373005930001 & $30-05-1993$ & $\begin{array}{l}\text { Kp.Babakan Ciyuda } \\
\text { 004/002 }\end{array}$ \\
\hline 5 & Kosim Mustopa & 3205370304920005 & $11-01-1994$ & Kp.Cinyawar 002/003 \\
\hline 6 & Riki Ruspandi & 3205371307950002 & $13-07-1995$ & Kp.Cinyawar 003/003 \\
\hline 7 & Pardi & 3205370506800004 & $05-08-1980$ & Kp.Cinyawar 003/003 \\
\hline 8 & Sarmana & 3205371207940001 & $05-07-1994$ & Kp.Cinyawar 004/004 \\
\hline 9 & Widi Heryadi & 3205370902000001 & $09-02-2000$ & Kp.Cinyawar 004/004 \\
\hline 10 & Tetin Priani & 3205374306990001 & $03-06-1999$ & Kp.Cinyawar 004/004 \\
\hline 11 & Mulyono & 3205371601900001 & $26-01-1990$ & Kp.Cinyatuh 005/004 \\
\hline 12 & Rian Saputra & 3205371708920002 & $17-08-1992$ & Kp.Cinyatuh 005/004 \\
\hline 13 & Dayep Saputra & 3205370905970004 & $09-05-1997$ & Kp.Selaawi II 002/005 \\
\hline 14 & Priatna & 3205371808780004 & $18-06-1978$ & Kp.Munjul 005/006 \\
\hline 15 & Tedi Purwanto & 3205370901910002 & $09-01-1991$ & $\begin{array}{l}\text { Kp.Mekar Hanja } \\
\text { 002/007 }\end{array}$ \\
\hline 15 & Daman & 3205370807940002 & $08-07-1994$ & Kp.Hanja 003/007 \\
\hline 17 & Uyan Irawan & 3205370410940002 & $04-10-1994$ & $\begin{array}{l}\text { Kp.Sirang Cibinong } \\
\text { 004/007 }\end{array}$ \\
\hline 18 & Didin Danto & 3205371206720004 & $12-06-1972$ & $\begin{array}{l}\text { Kp.Sirang Cibinong } \\
\text { 004/007 }\end{array}$ \\
\hline 19 & Wawan. A & 3205371006010001 & $09-07-1999$ & $\begin{array}{l}\text { Kp.Sirang Cibinong } \\
\text { 004/007 }\end{array}$ \\
\hline 20 & Sesep Pirman & 3205371402930001 & $14-12-1993$ & Kp.Panyeredan 001/007 \\
\hline 21 & Tardin & 3205371301840001 & $13-01-1984$ & $\begin{array}{l}\text { Kp.Mekar Hanja } \\
\text { 002/007 }\end{array}$ \\
\hline 22 & Dadang & 3205370705950001 & $07-05-1995$ & Kp.Urug 007/008 \\
\hline
\end{tabular}




\begin{tabular}{|c|l|c|c|l|}
\hline No & Nama Penerima & NIK & $\begin{array}{c}\text { Tanggal } \\
\text { Lahir }\end{array}$ & \multicolumn{1}{|c|}{ Alamat Lengkap } \\
\hline 23 & Dudi Koswara & 3205370801840001 & $08-01-1984$ & Kp.Urug 007/008 \\
\hline 24 & Ujang Karmin & 3205371212820002 & $12-12-1982$ & Kp.Urug 007/008 \\
\hline
\end{tabular}

Berdasarkan tabel dan uraian diatas menunjukan berbagai langkah yang dilakukan pemerintah desa untuk Penanganan Covid-19, Padat Karya Tunai, Bantuan Langsung Tunai dan Sembako dengan mengunakan anggaran yang bersumber dari Dana Desa (DD), Bantuan Provinsi dan Alokasi Dana Desa (ADD) namun dalam keberlangsungannya tersebut masih kurang efektif (Hastuti, 2013).

Efektivitas pada hakikatnya berorientasi pada pencapaian tujuan yang telah ditentukan sebelumnya maka perbuatan itu dikatakan efektif kalau menimbulkan akibat atau mencapai maksud sebagaimana yang dikehendaki. Berdasarkan uraian di atas maka peneliti tertarik untuk melakukan penelitian tentang Efektivitas Pengelolaan Anggaran Pendapatan dan Belanja Desa (APBDes) Di Masa Pandemi Covid-19. Untuk itu peneliti melakukan penelitian dan menyajikannya hasil penelitian tersebut dalam bentuk skripsi dengan judul "Efektivitas Pengelolaan Anggaran Pendapatan dan Belanja Desa (APBDes) Perspektif Permendes Nomor 7 Tahun 2020 Perubahan Kedua tentang Prioritas Penggunaan Dana Desa Di Masa Pandemi Covid-19 di Desa Selaawi Kecamatan Talegong Kabupaten Garut.”

\section{IDENTIFIKASI MASALAH DAN RUMUSAN MASALAH}

Berdasarkan paparan latar belakang, maka permasalahan yang bisa diidentifikasi peneliti adalah:

1. Pandemi Covid-19 merubah anggaran belanja untuk kegiatan penanganan dan penanggulangan Covid-19 yang berdampak terbengkalainya penganggaran sebelumnya yang pastinya terabaikan Pembangunan Infrastruktur.

2. Langkah pemerintah desa dalam penanganan Covid-19 masih kurang efektif. Dijumpai bahwa orang-orang tidak mengindahkan larangan pemerintah agar melakukan social distancing dan physical distancing (tidak berkerumun) masyarakat yang tidak memakai masker dan enggan mencuci tangan dengan sabun atau cairan disinfektan.

3. Pembangunan Padat Karya Tunai kurang efektif bagi penduduk miskin yang terlibat dalam proyek tersebut sebagai tenaga kuli harian sesungguhnya 
manfaatnya sangatlah temporer bahkan nyaris tidak berbekas dengan diberikanya upah.

4. Bantuan Langsung Tunai masih kurang efektif adanya penerima dana bantuan yang sebenarnya tidak layak menerima namun menerima juga sebaliknya ada yang terlihat layak namun tidak menerima data penerima yang tidak akurat dan pemanfaatan uangnya dipergunakan untuk hal yang kurang bermanfaat.

Berdasarkan latar belakang dan identifikasi masalah yang telah dikemukakan di atas, maka permasalahan yang akan dibahas dalam penelitian ini adalah Bagaimana Efektivitas Pengelolaan Anggaran Pendapatan dan Belanja Desa (APBDes) Perspektif Permendes Nomor 7 Tahun 2020 Tentang Prioritas Penggunaan Dana Desa Di Masa Pandemi Covid-19 di Desa Selaawi?

\section{KERANGKA PEMIKIRAN}

Menurut Martani dan Lubis (1987) menyatakan efektivitas merupakan unsur pokok aktivitas untuk mencapai tujuan atau sasaran yang ditentukan sebelumnya. Dengan kata lain suatu organisasi disebut efektif apabila tercapai tujuan atau sasaran yang telah ditentukan sebelumnya. Jadi efektivitas sebagai konsep yang sangat penting dalam organisasi karena menjadi ukuran keberhasilan organisasi dalam mencapai tujuannya. Karena pengukuran efektifitas bukanlah hal yang sederhana mengingat perbedaan tujuan masing-masing organisasi dan keragaman tujuan organisasi itu sendiri (Umi, 2015).

Martani dan Lubis (1987) menyebutkan 3 (tiga) pendekatan utama dalam pengukuran efektivitas organisasi yaitu:

1. Pendekatan sumber. Pendekatan ini mengukur efektivitas dari sisi input yaitu dengan mengukur keberhasilan organisasi publik dalam mendapatkan sumbersumber yang dibutuhkan.

2. Pendekatan proses. Pendekatan ini menekankan pada aspek internal organisasi publik yaitu dengan melihat sejauh mana efektivitas pelaksanaan program dari semua kegiatan proses internal atau mekanisme organisasi.

3. Pendekatan sasaran. Pendekatan ini memusatkan perhatiannya dalam mengukur efektivitas pada aspek output yaitu dengan mengukur keberhasilan organisasi publik dalam mencapai tingkatan output yang direncanakan.

Peraturan Menteri Desa, Pembangunan Daerah Tertinggal dan Transmigrasi Nomor 7 Tahun 2020 merupakan perubahan kedua dari Peraturan Menteri Desa, Pembangunan Daerah Tertinggal dan Transmigras Nomor 11 Tahun 2019 Tentang Prioritas Penggunaan 
Dana Desa Tahun 2020. Dalam Peraturan Menteri Desa, Pembangunan Daerah Tertinggal dan Transmigras Nomor 11 Tahun 2019 dijelaskan prioritas dana desa tahun 2020 diantaranya: a. Pelaksanaan pembangunan desa dengan pola padat karya tunai; $b$. Pencegahan kekurangan gizi kronis (stunting); c. Pengembangan anak usia dini holistic intergratif (paud hi); d. Pelaksanaan Keamanan pangan di desa; e. Pelayanan Pendidikan bagi anak; f. Pengembangan ketahanan dan kesejahteraan keluarga; g. Pencegahan penyalagunaan dan peredaran gelap narkoba; h. Pembelajaran dan pelatihan kerja; i. Pengembangan Desa inklusi; j. Pengembangan produk unggulan desa/Kawasan perdesaan; k. Pembentukan dan pengembangan Bumdesa/Bumdesa Bersama; 1. Pembangunan dan pengelolaan pasar desa; m. Pembangunan embung desa terpadu; $n$. Pengembangan desa wisata; o. Pendayagunaan sumberdaya alam dan teknologi tepat guna; p. Pengendalian perubahan iklim melalui mitigasi dan adaptasi; q. Pencegahan dan penanganan bencana alam; r. Kegiatan tanggap darurat bencana alam; s. Sistem informasi desa; t. Pengembangan keterbukaan informasi pembangunan desa; u. Pemberdayaan hukum di desa. Prioritas Penggunan dana desa tersebut dialihkan menjadi:
a. Penanggulangan Covid-19 di desa
b. Padat Karya Tunai Desa (PKTD)
c. Bantuan Langsung Tunai (BLT)

\section{METODE PENELITIAN}

Menurut Emzir (2010) penelitian kualitatif merupakan penelitian lapangan atau penelitian interpretatif yang bersumber dari kepercayaan dalam hal ini pengetahuan dihasilkan dari segi sosial dan bahwa pemahaman pengetahuan sosial merupakan suatu proses ilmiah legitimate. Pada penelitian kualitatif peneliti berperan sebagai instrumen penelitian berbeda dengan penelitian kuantitatif yang melakukan analisis statistik untuk menjawab rumusan masalah.

Menurut Sugiyono (2013) metode penelitian kualitatif adalah metode penelitian yang digunakan untuk meliputi pada kondisi obyek yang alamiah (sebagai lawannya adalah eksperimen) dimana peneliti adalah sebagai instrumen kunci teknik pengumpulan data dilakukan secara triangulasi (gabungan) analisis bersifat induktif dan hasil penelitian kualitatif lebih menekankan makna daripada generalisasi. Pemilihan jenis penelitian kualitatif dalam penelitian ini dilakukan untuk lebih dapat mengungkap peristiwa dan fakta-fakta yang sesuai dengan judul penelitian yakni efektivitas pengelolaan anggaran 
pendapatan dan belanja desa (APBDes) Perspektif Permendes Nomor 7 Tahun 2020 Tentang Prioritas Penggunaan Dana Desa di masa pandemi covid-19.

\section{HASIL DAN PEMBAHASAN}

Secara umum efektivitas bisa diartikan dengan seberapa jauh tercapainya tujuan dari suatu organisasi atau program. Efektivitas dalam penelitian ini berarti tercapainya tujuan pelaksanaan Pengelolaan Anggaran Pendapatan dan Belanja Desa Perspektif Permendes Nomor 7 Tahun 2020 Perubahan Kedua tentang Prioritas Penggunaan Dana Desa di Masa Pandemi Covid-19 yang dilaksanakan oleh Pemerintah Desa di Desa Selaawi Kecamatan Talegong Kabupaten Garut dengan cara melihat output yang dihasilkan melalui pelaksanaan program-program Pencegahan dan penanganan covid-19, Padat karya tunai desa dan Bantuan langsung tunai desa.

Mengukur tingkat efektivitas Pencegahan dan penanganan covid-19, Padat karya tunai dan Bantuan langsung tunai di Desa Selaawi Kecamatan Talegong Kabupaten Garut peneliti menggunakan teori dari Martani dan Lubis yaitu tingkat efektivitas diukur menggunakan 3 (tiga) pendekatan yaitu Pendekatan sumber (resource approach), Pendekatan proses (process approach) dan Pendekatan sasaran (goals approach). Selanjutnya dijabarkan melalui hasil penelitian di lapangan sebagai berikut:

\section{Pendekatan Sumber (Resource Approach)}

Anggaran Pendapatan dan Belanja Desa APBDes adalah peraturan desa yang memuat sumber-sumber penerimaan dan alokasi pengeluaran desa dalam kurun waktu satu tahun. APBDes terdiri atas bagian pendapatan desa, belanja desa dan pembiayaan. Pendapatan desa merupakan penghasilan yang diperoleh desa yang bersumber dari pendapatan asli desa, pendapatan transfer ataupun pendapatan lain-lain desa. Pendapatan transfer Desa Selaawi berasal dari Dana Desa, Alokasi Dana Desa, Bantuan Keuangan Provinsi, Bagi Hasil Pajak dan Retribusi serta Bantuan Keuangan Kabupaten. Sumber pendapatan desa pengelolaannya dilakukan dalam kerangka pengelolaan Keuangan Desa. Keuangan desa dikelola berdasarkan asas-asas transparan, akuntabel, partisipatif, serta dilakukan dengan tertib dan disiplin anggaran secara efektif. Untuk mengetahui Pendekatan sumber (resource approach) Pencegahan dan penangan covid-19, Padat karya tunai dan Bantuan langsung tunai di Desa Selaawi Kecamatan Talegong Kabupaten Garut peneliti mewawancarai informan kepala Desa Selaawi beliau mengatakan:

"Desa Selaawi mempunyai sumber anggaran tahun 2020 diantaranya Pendapatan Asli Desa sebesar Rp. 8.100.000, Dana Desa sebesar Rp. 
1.199.914.000, Bagi Hasil Pajak dan Retrebusi sebesar Rp. 41.479.100, Alokasi Dana Desa sebesar Rp. 530.879.557, Bantuan Keuangan Provinsi sebesar Rp. 130.000.000, Bantuan Keuangan Kabupaten Kota sebeara Rp. 40.000.000 semua itu termuat dalam APBDes.”

Hal ini sesuai dengan pernyataan Sekretaris Desa Selaawi dalam kutipan wawancara yang berbunyi:

"Sejak diterbitkannya Permendes Nomor 7 Tahun 2020 bahwa prioritas pengunaaam dana desa diprioritaskan untuk pencegahan dan penanganan covid-19, Bantuan langsung tunai, Padat karya tunai untuk menjalankan peraturan tersebut kami pemerintah desa mengambil dari sumber anggaran Bantuan Provinsi dan Dana Desa.”

Untuk lebih jelasnya peneliti mendapatkan sumber data penganganggaran Penanganan dan Pencegahan covid-19, Padat karya tunai dan Bantuan Langsung Tunai dapat dilihat dalam tabel berikut:

Tabel 6. Sumber Anggaran Penanganan dan Pencegahan Covid-19 Padat Karya Tunai dan Bantuan Langsung Tunai Desa Selaawi Tahun 2020

\begin{tabular}{|c|l|r|c|}
\hline No & \multicolumn{1}{|c|}{ Uraian } & Anggaran Rp & Sumber Anggaran \\
\hline 1. & Penanganan Covid-19 & 98.100 .00 & Bantuan Provinsi \\
\hline 2. & Penanganan Covid-19 & 8.519 .000 & \multirow{2}{*}{ Dana Desa } \\
\hline 3. & Gebrak Seribu Masker & 21.000 .000 & \\
\hline 4. & Bantuan Langsung Tunai & 504.000 .000 & \\
\hline 5. & Pembukaan Jalan Baru (PKT) & 48.625 .000 & \\
\hline
\end{tabular}

Sumber: Data dari APBDes Perubahan Desa Selaawi Tahun 2020 (data diolah)

Rasio efektivitas digunakan untuk memudahkan dalam memberikan simpulan dari perhitungan yang telah dilakukan melalui analisis efektivitas (Rinda, 2020). Adapun rasio efektivitas yang digunakan Kepmendagri No 690.900.327 Tahun 1996 yaitu:

1) Hasil perbandingan antara pendapatan dengan realisasi belanja yang di prioritaskan jika pencapaiannya di atas 100\% dapat dikatakan sangat efektif.

2) Hasil perbandingan antara pendapatan dengan realisasi belanja yang di prioritaskan jika tingkat pencapaiannya 90-100\% dapat dikatakan efektif.

3) Hasil perbandingan antara pendapatan dengan realisasi belanja yang di prioritaskan jika tingkat pencapaiannya 80-89\% dapat dikatakan cukup efektif.

4) Hasil perbandingan antara pendapatan dengan realisasi belanja yang di prioritaskan jika tangka pencapaiannya 60-79\% dapat dikatakan kurang efektif.

5) Hasil perbandingan antara pendapatan dengan realisasi belanja yang di prioritaskan jika tingkat pencapaiannya $<60 \%$ dapat dikatakan tidak efektif. 
Berdasarkan perhitungan yang dilakukan melalui analisis efektivitas dapat dipaparkan Efektivitas Pengelolan Anggaran Pendapatan Dan Belanja Desa APBDes Perspektif Permendes Nomor 7 Tahun 2020 Tentang Prioritas Penggunaan Dana Desa di Desa Selaawi sebagai berikut:

Tabel 7. Rekapitulasi Pagu Anggaran Pendapatan dan Belanja Desa Selaawi Tahun 2020

\begin{tabular}{|c|c|c|c|c|c|c|c|}
\hline \multirow{2}{*}{\multicolumn{2}{|c|}{ Pendapatan Desa (Rp) }} & \multicolumn{6}{|c|}{ Anggaran Belanja } \\
\hline & & \multirow{2}{*}{$\begin{array}{c}\begin{array}{c}\text { Pencegahan } \\
\text { dan } \\
\text { Penanganan } \\
\text { Covid-19 }\end{array} \\
-\end{array}$} & \multirow{2}{*}{$\begin{array}{l}(\%) \\
0.0 \%\end{array}$} & \multirow{2}{*}{$\begin{array}{l}\text { Padat } \\
\text { Karya } \\
\text { Tunai } \\
\end{array}$} & \multirow{2}{*}{$\begin{array}{l}(\%) \\
0.0 \%\end{array}$} & \multirow{2}{*}{$\begin{array}{c}\text { Bantuan } \\
\text { Langsung } \\
\text { Tunai dan } \\
\text { Sembako }\end{array}$} & \multirow{2}{*}{$\begin{array}{l}(\%) \\
0.0 \%\end{array}$} \\
\hline $\begin{array}{l}\text { Pendapatan } \\
\text { Asli Desa }\end{array}$ & 8.100 .000 & & & & & & \\
\hline Dana Desa & 1.199 .914 .000 & 29.519 .000 & $2.5 \%$ & 48.625 .000 & $4.1 \%$ & 504.000 .000 & $42.0 \%$ \\
\hline $\begin{array}{lr}\text { Bagi } & \text { Hasil } \\
\text { Pajak dan } \\
\text { Retrebusi }\end{array}$ & 41.479 .100 & - & $0.0 \%$ & - & $0.0 \%$ & - & $0.0 \%$ \\
\hline $\begin{array}{l}\text { Alokasi } \\
\text { Dana Desa }\end{array}$ & 530.879 .557 & - & $0.0 \%$ & - & $0.0 \%$ & 80.000 .000 & $15.1 \%$ \\
\hline $\begin{array}{l}\text { Bantuan } \\
\text { Keuangan } \\
\text { Provinsi }\end{array}$ & 130.000 .000 & 98.100 .000 & $75.5 \%$ & - & $0.0 \%$ & - & $0.0 \%$ \\
\hline $\begin{array}{l}\text { Bantuan } \\
\text { Keuangan } \\
\text { Kabupaten } \\
\text { Kota }\end{array}$ & 40.000 .000 & - & $0.0 \%$ & - & $0.0 \%$ & - & $0.0 \%$ \\
\hline $\begin{array}{l}\text { Pendapatan } \\
\text { lain }\end{array}$ & 12.316 .292 & - & $0.0 \%$ & - & $0.0 \%$ & - & $0.0 \%$ \\
\hline Jumlah & 1.962.688.949 & 127.619.000 & $77.9 \%$ & 48.625.000 & $4.1 \%$ & 584.000 .000 & $57.1 \%$ \\
\hline
\end{tabular}

Sumber: Data dari APBDes Perubahan Desa Selaawi Tahun 2020 (data diolah)

Dari hasil penelitian mengenai pendekatan sumber pemerintah desa sudah bekerja sesuai dengan prosedur serta mengambil sumber anggran dari Bantuan Provinsi dan Dana Desa dalam Penanganan dan pencegahan covid-19, Bantuan langsung tunai dan Padat karya tuni. Desa telah mengunakan sumber tersebut sesuai dengan perundang-undangan yang berlaku dan juga berdasarkan hasil data sekunder dilapangan menyatakan demikian. Sedangakan berdasarkan kriteria rasio efektivitas Pengelolaan Anggaran Pendapatan dan Belanja Desa di Desa Selaawi tahun 2020 berada dalam kategori tidak efektif karena tingkat efektivitasnya berada pada angka rata-rata $46.3 \%$.

\section{Pendekatan Proses (Process Approach)}

Proses merupakan suatu tahapan-tahapan yang diterapkan dari suatu pekerjaan sehingga hasil yang dicapai dari pekerjaan tersebut mampu menggambarkan baiknya prosedur yang digunakan. Pemerintah Desa sebagai pelaksana yang melaksanakan 
program-program melalui mekanisme yang sesuai dengan Permendagri Nomor 20 Tahun 2018 tentang Pengelolaan Keuangan Desa mulai dari perencanaan, pelaksanaan, penatausahaan, pelaporan hingga pertanggungjawaban secara tertib dan transparan. Proses pengelolaan keuangan desa di Desa Selaawi sebagai berikut:

1) Tahap Perencanaan

Perencanaan adalah awal dari sebuah kegiatan bila perencanaan itu dilakukan dengan tepat dan baik akan memberikan pengaruh yang besar terhadap pelaksanaan dan kemudian hasil kegiatan yang efektif. Sesuai dengan Permendagri Nomor 20 Tahun 2018 bahwa Kepala Desa selaku pemegang kekuasaan pengelolaan keuangan mempunyai kewenangan menyusun APBDes. APBDes merupakan pembiayaan terhadap program pembangunan tahunan yang diselenggarakan oleh pemerintahan desa (Supriyono, 2004).

Perencanaan anggaran pendapatan dan belanja desa di Desa Selaawi oleh kepala desa dengan BPD. APBDes yang ditetapkan oleh kepala desa dan BPD merupakan APBDes yang ditetapkan dari hasil penyusunan rancangan APBDes yang dibuat oleh Kepala Desa dengan mendengarkan aspirasi masyarakat desa setiap tahun harus melaporkan laporan pertanggungjawabkan anggaran pendapatan dan belanja desa. Sekretaris Desa menyusun rancangan peraturan desa tentang APBDes berdasarkan RKPDes sekretaris desa menyampaikan rancangan peraturan desa tentang APBDes kepada kepala desa menyampaikan rancangan peraturan desa kepada BPD untuk dibahas bersama dalam rangka memperoleh persetujuan bersama. Rancangan Peraturan Desa tentang Anggaran Pendapatan dan Belanja Desa yang telah disetujui bersama sebelum ditetapkan oleh kepala desa paling lambat 3(tiga) hari kerja disampaikan kepada Bupati/Walikota untuk dievaluasi. Bupati/Wali Kota harus mengevaluasi rancangan APBDes hasil evaluasi tersebut kepala desa dapat menetapkan rancangan peraturan desa tentang APBDes menjadi peraturan desa.

2) Tahap Pelaksanaan

Pelaksanaan Anggaran Pendapatan dan Belanja Desa yang tertuang dalam Permendagri Nomor 20 Tahun 2018 bahwa Semua penerimaan dan pengeluaran desa dalam rangka pelaksanaan kewenangan desa dilaksanakan melalui rekening kas desa pelaksanaan pengelolaan APBDes sesuai dengan yang telah direncanakan serta perubahan dalam APBDes dan semuanya tercatat dan pelaksana kegiatan yang bertanggungjawab terhadap tindakan pengeluaran mempergunakan buku pembantu kas kegiatan sebagai pertanggungjawaban pelaksanaan kegiatan didesa berjalan secara efektif. 
Pengelolaan APBDes pada tahap pelaksanaan di atas menggambarkan bahwa pengelolaan APBDes dalam tahap pelaksanaan APBDes tahun 2020 di Desa selaawi telah terlaksana dengan baik dan sudah sesuai dengan peraturan diantaranya yaitu bahwa semua penerimaan dan pengeluaran dalam rangka pelaksanaan kewanangan desa dilaksanakan melalui rekening kas desa dan Pemerintah desa dilarang melakukan pungutan sebagai penerimaan desa juga.

3) Tahap Penatausahaan

Penatausahaan APBDes yaitu bahwa kegiatan ini yang nyaris dilakukan sepanjang tahun anggaran. Kegiatan ini bertumpu pada tugas dan tanggungjawab Bendahara yaitu pencatatan pengeluaran dan pemasukan. Ketekunan dan ketelitian menjadi syarat dalam melaksanakan kegiatan ini. Menurut Permnedagri Nomor 20 tahun 2018 Penatausahaan adalah rangkaian kegiatan yang dilakukan secara sistematis (teratur dan masuk akal/logis) dalam bidang keuangan berdasarkan prinsip standar serta prosedur tertentu sehingga informasi aktual (informasi yang sesungguhnya) berkenaan dengan keuangan dapat segera diperoleh. Tahap ini merupakan proses pencatatan seluruh transaksi keuangan yang terjadi dalam satu tahun anggaran. Hasil dari penatausahaan adalah laporan yang dapat digunakan untuk pertanggungjawaban pengelolaan keuangan itu sendiri pencatatan seluruh transaksi keuangan baik penerimaan maupun pengeluaran uang dalam satu tahun anggaran.

Pada tahap Penatausahaan diatas bahwa setiap kegiatan atau program yang sumber dananya dari APBDes telah di catat dalam Buku Kas Umum, Buku Bank dan Buku Kas Pembantu, juga bukti transaksi sesuai dengan ketentuan yang berlaku seperti dibuatkan surat perintah pencairan dana, surat perintah membayar langsung, kwitansi penggunaan anggaran dan surat permintaan pembayaran langsung belanja pengeluaran. Jadi pada tahap penatausahaan yang telah dilakukan di Desa Selaawi telah memenuhi syarat serta efektif dengan hasil yaitu laporan keuangan yang tercatat catat dalam Buku Kas Umum, Buku Bank dan Buku Kas Pembantu juga bukti transaksi sesuai dengan ketentuan yang berlaku hal ini sesuai dengan Peratuaran.

4) Tahap Pelaporan

Bendahara desa wajib mempertanggungjawabkan penerimaan uang yang menjadi tanggung jawabnya melalui laporan pertanggungjawaban penerimaan kepada kepala desa. Pelaporan Anggaran Pendapatan dan Belanja Desa sudah memenuhi ketentuan dan peraturan yang ada dan dalam memenuhi laporan pertanggungjawaban yang ada sudah 
memenuhi LPJ, LPPD dan bukti-bukti dalam realisasi keuangan anggaran pendapatan dan belanja desa.

5) Pertanggungjawaban

Peraturan desa tentang pertanggung jawaban pelaksanaan APBDes dan keputusan kepala desa tentang keterangan pertanggungjawaban kepala desa disampaikan kepada Bupati/Walikota melalui Camat. Waktu penyampaian paling lambat 7 tujuh hari kerja setelah peraturan desa ditetapkan.

Desa Selaawi sudah memenuhi laporan pertanggungjawaban dengan menyerahkan laporan pertanggung jawaban melalui pengumpulan di Kecamatan. Pengelola APBDes tingkat desa sudah memenuhi ketentuan pembuatan laporan semester dan laporan akhir kegiatan kemudian Kepala Desa menyampaikan laporan pertanggungjawaban realisasi pelaksanaan APBDes kepada Bupati/Walikota setiap akhir tahun anggaran. Pengelolaan keuangan desa harus dilakukan secara efektif, transparan dan akuntabel. Informasiinformasi tersebut menunjukkan bahwa pertanggungjawaban pelaksanaan program APBDes di Desa Selaawi telah menerapkan tingkat keefektifan walaupun belum sempurna. Pengelolaan APBDes tetap dituntut pertanggungjawaban pada setiap pembelanjaan uang. Dengan demikian apabila hal tersebut dilakukan secara terus menerus tertib dan sesuai dengan ketentuan yang ada maka dapat meringankan/mendukung penyusunan pertanggungjawaban akhir kegiatan APBDes yang harus disusun oleh Tim Pelaksana Desa. Proses Pengelolaan Anggaran Pendapatan dan Belanja Desa (APBDes) di Desa Selaawi dapat digambarkan sebagai berikut:

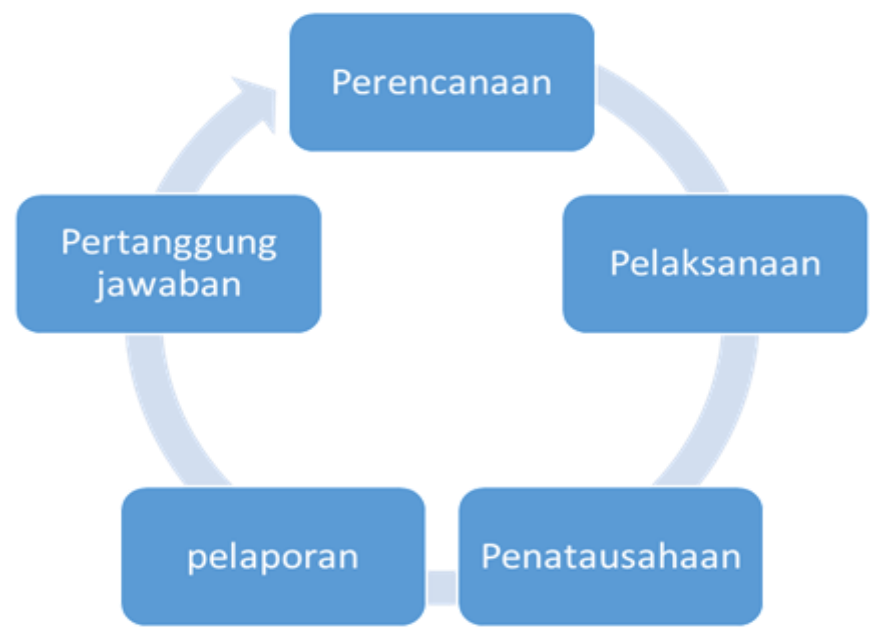

Gambar 1. Siklus Pengelolaan Anggaran Pendapatan dan Belanja Desa

Sumber: (padk, 2018) 


\section{Pendekatan Sasaran (Goals Approach)}

Penggunaan anggaran Dana Desa harus tepat sasaran agar memberikan dampak dan manfaat yang besar bagi masyarakat sehingga penyusunan rencana anggaran Dana Desa harus memprioritaskan kegiatan berdasarkan kebutuhan masyarakat tersebut. Pada tahun 2020 ini tidak bisa dipungkiri bahwasannya semua desa yang ada di Kabupaten Garut terdampak sebuah wabah covid-19 dimana Desa Selaawi adalah desa yang tidak ditemukannya kasus yang terkonfirmasi positif covid-19. Dengan adanya pandemi covid19 Pemerintah Desa Selaawi bergerak cepat dalam memutus rantai penyebaran covid-19 di Desa Selaawi meskipun termasuk pada zona hijau, salah satunya dengan cara melakukan perubahan APBDes. Sebelum dilakukan perubahan APBDes di Tahun 2020 Desa Selaawi mendapatkan anggaran APBDes sebesar Rp. 1.948.070.913.- setelah perubahan menjadi Rp. 1.962.688.948.- dana tersebut diprioritaskan untuk penanganan Covid-19 antara lain:

1. Kegiatan Pencegahan dan penanggulangan Covid-19 sebesar Rp. 127.619.000.antara lain:

a. Pembentukan Satgas Covid-19

b. Penyemprotan disinfektan dilaksanakan di rumah warga, jalan dan tempat fasilitas umum yang ada di Desa Selaawi penyemprotan dilaksanakan selama 14 kali penyemprotan.

c. Pembagian masker ke masyarakat dan tempat cuci tangan di area faslitas umum.

Mengetahui keberhasilan pemerintah desa dalam Pencegahan dan penanganan covid-19 realisasi output dari Penanganan dan pencegahan covid-19 diambil kesimpulan bahwa pendekatan sasaran goals approach kinerja pemerintah desa mendapatkan apresiasi dari masyarakat. Satgas covid-19 masih harus terus memperbaiki segala macam isu dan tantangan yang dihadapi dengan lebih agresif dan memiliki semangat yang konsisten sehingga mampu berjuang untuk menangani pandemi dengan profesional dan optimal. Pada konteks ini produktivitas satgas covid-19 juga terkait dengan partisipasi masyarakat jika partisipasi masyarakat baik maka kinerja satgas covid-19 juga akan semakin meningkat dan efektif.

2. Padat Karya Tunai Desa (PKTD)

Kegiatan Padat Karya Tunai Desa Selaawi di laksanakan dalam bentuk Pembangunan jalan baru RT 06 sebesar Rp. 48.625.000.- Kegiatan PKT Desa Selaawi mengerahkan 50 masyarakat dalam bentuk pemberian upah sebesar Rp. 65.000 per hari selama 14 hari kerja. Melalui program padat karya tunai yang menggunakan dana desa di 
mana suatu pembangunan di desa dilakukan secara swakelola dan pekerja pembangunan diupah harian atau setiap minggunya. Dengan demikian dana desa tidak hanya digunakan untuk membeli bahan material infrastruktur saja melainkan juga untuk membayar upah pekerja. Padat karya tunai yang terkawal dikatakan efektif diharapkan padat karya tunai ini dapat menjadi solusi untuk menekan tingkat pengangguran dan tingkat kemiskinan artinya dengan program padat karya tunai masyarakat secara langsung dapat menerima uang tunai yang dimaksud dari hasil kerja yang mereka kerjakan.

3. Bantuan Langsung Tunai Dana Desa (BLT-DD)

Angaran Dana Desa Selaawi dalam Bantuan Langsung Tunai masuk dalam kategori Belanja Tidak Terduga Sub Bidang Penanggulangan Bencana dengan total Rp. 504.000.000.- Pencairan BLT-DD dan Keluarga Penerima Manfaat (KPM) Desa Selaawi di bagi menjadi 3 Tahap yakni:

a. Tahap I bulan April, Mei dan Juni dengan besaran Rp. 600.000/KPM dengan total 140 KPM.

b. Tahap II bulan Juli, Agustus dan September dengan besaran Rp. 300.000/KPM dengan total 140 KPM.

c. Tahap III bulan Oktober, November dan Desember dengan besaran Rp. 300.000/KPM dengan total 140 KPM.

Dalam rangka penanganan dampak covid 19 khususnya dampak ekonomi pemerintah Desa memberikan Bantuan Langsung Tunai yang diambil dari dana desa yang kemudian disalurkan kepada masyarakat melalui mekanisme yang ditetapkan. Jika dilihat efektifitasnya dari program tersebut terkait dengan penyaluran BLT Dana Desa di Desa Selaawi dapat disimpulkan sudah tepat dan mengikuti mekanisme yang ada. Pemerintah desa sudah bekerja sesuai dengan prosedur, mengenai adanya dugaan nepotisme dalam penentuan penerima BLT Dana Desa telah di bantah oleh Kepala Desa dan berdasarkan hasil data sekunder dilapangan menyatakan demikian dan untuk aspek ketepatatan sasaran dapat disimpulkan bahwa pemberian bantuan langsung tunai dana desa di Desa Selaawi Kecamatan Talegong sudah tepat sasaran. Hal tersebut didasari oleh pernyataan masyarakat yang merasakan langsung dampak BLT dan merupakan pelaku langsung di lapangan.

\section{KESIMPULAN}

Sumber Anggaran Pendapatan dan Belanja Desa APBDes terdiri dari pendapatan asli desa, pendapatan transfer ataupun pendapatan lain-lain desa. Pendapatan Transfer 
Desa Selaawi berasal dari Dana Desa, Alokasi Dana Desa, Bagi Hasil Pajak dan Retribusi dan Bantuan Keuangan Kabupaten. Sejak diterbitkanya Permendes Nomor 7 tahun 2020 Perubahan Kedua tentang Prioritas Pengunaan Dana Desa bahwa dana desa diprioritaskan untuk penanganan dan pencegahan covid-19, Bantuan langsung tunai dan Padat karya tuni. Dalam menjalankan peraturan tersebut Pemerintah Desa Selaawi mengunakan sumber anggaran dari Bantuan provinsi dan Dana Desa. Melaksanakan program tersebut desa mengalami hambatan keterlambatan pencairan dana desa serta adanya kebijakan yang berubah-ubah. Pemerintah mengupayakan tindakan untuk membantu perekonomian masyarakat yang terdampak pandemi Covid-19 dengan merubah sumber anggaran kegiatan pembangunan yang diawali dengan musyawarah khusus. Pemerintah Desa berhasil mendapatkan sumber-sumber angaran untuk Desa dan melaksanakan program telah menerapkan tingkat keefektifan walaupun belum sempurna Sedangkan Proses Pemerintah Desa Selaawi sebagai pelaksana yang melaksanakan program-program melalui mekanisme yang sesuai. mulai dari perencanaan, pelaksanaan, penatausahaan, pelaporan hingga pertanggungjawaban. Perencanaan dilakukan Sekretaris Desa untuk dibahas dan disepakati bersama. Pelaksana kegiatan melaksanakan kegiatan dilengkapi dengan dokumen-dokumen yang telah diverifikasi Sekretaris Desa dan disahkan oleh Kepala Desa. Penatausahaan dilakukan Bendahara tiap Desa dengan mencatat setiap penerimaan dan pengeluaran serta melakukan tutup buku tiap akhir bulan. Laporan realisasi pelaksanaan APBDes dilakukan oleh setiap Kepala Desa kepada Bupati berupa laporan semester pertama dan laporan semester akhir tahun. Pertanggungjawaban pelaksanaan menjadi tanggungjawab Kepala Desa menyampaikan laporan pertanggungjawaban realisasi APBDes yang terdiri dari laporan pendapatan, belanja dan pembiayaan kepada Bupati pada akhir tahun anggaran. Proses tersebut dapat dikatakan efektif.

Sedangkan Sasaran Penggunaan APBDes diprioritaskan untuk penanganan dan pencegahan covid-19, Bantuan langsung tunai dan Padat karya tunai. Padat karya tunai yang menggunakan dana desa di mana suatu pembangunan di desa dilakukan secara swakelola dan pekerja pembangunan di upah harian atau setiap minggunya tidak hanya digunakan untuk membeli bahan material saja melainkan juga untuk membayar upah pekerja. Bantuan Langsung Tunai yang diambil dari dana desa yang kemudian disalurkan kepada masyarakat melalui mekanisme yang ditetapkan sudah tepat dan mengikuti mekanisme yang ada Pemerintah Desa sudah bekerja sesuai dengan prosedur. Sebagian masyarakat secara sadar dan kritis mengikuti mekanisme pembatasan sosial tetapi 
sebagian lagi belum berpartisipasi masyarakat desa selaawi masih belum mengindahkan larangan pemerintah agar melakukan sosial distancing dan phisical distancing (tidak berkerumun) masyarakat yang tidak memakai masker dan enggan mencuci tangan dengan sabun atau cairan disinfektan. Upaya Pemerintah Desa dalam Menanggapi covid-19 di Desa Selaawi Kecamatan Talegong Kabupaten Garut sesuai dengan Regulasi yang ditetapkan Pemerintah Pusat melalui Permendes Nomor 7 Tahun 2020 Perubahan Kedua tentang Prioritas Pengunaan Dana Desa hal tersebut dibuktikan dengan terlaksananya program-program yang diatur dalam regulasi tersebut sebagai upaya Penanganan covid19, Bantuan langsung tunai dan Padat karya tunai. Respon masyarakat terhadap upaya pemerintah Desa Selaawi menggambarkan hal yang positif meskipun beberapa hal masih menunjukkan respon negatif. Pemerintah Desa telah menerapkan tingkat keefektifan walaupun belum sempurna dengan terlaksananya program tersebut serta upaya yang dilakukan oleh Pemerintah Desa dalam pencegahan covid-19.

Anggaran Pendapatan dan Belanja Desa sebagai rencana keuangan tahunan pemerintah desa yang dibahas dan disetujui bersama oleh pemerintah desa dan Badan Permusyawaratan Desa dibahas dalam musyawarah perencanaan pembangunan desa. Anggaran desa di Desa Selaawi Kecamatan Talegong Kabupaten Garut melalui Permendes Nomor 7 Tahun 2020 Perubahan Kedua yang mengatur mengenai perubahan prioritas dana desa untuk: Penanggulangan Covid-19, Padat karya tunai desa, Bantuan langsung tunai. Penerapan efektivitas serapan anggaran yang diperoleh dari hasil penelitian ini menunjukkan tingkat pencapaian kinerja Pemerintah Desa dalam Pencegahan dan penanganan covid-19, Padat karya tunai dan Bantuan langsung tunai Pemerintah Desa telah menerapkan tingkat keefektifan walaupun belum sempurna. Pengelolaan Anggaran Pendapatan dan Belanja Desa harus lebih efektif perlu adanya peningkatan kualitas sumber daya manusia aparatur desa khususnya kepala desa, kepala urusan keuangan desa, dan tim pelaksana kegiatan serta menyampaikan aspirasi pemerintah desa ke pemerintah pusat.

\section{DAFTAR PUSTAKA}

Adisasmita, Rahardjo. 2011. Pengelolaan Pendapatan dan Anggaran Daerah. Yogyakarta: Graha Ilmu.

Akhir, Hasbi. 2012. BLT Temporary Unconditional Cash Transfer (SocialAssistance Program and Public Expenditure Review 2). Jakarta: The World Bank. 
Carly Erfly Fernando Maun. 2020. Efektivitas Bantuan Langsung Tunai Dana Desa Bagi Masyarakat Miskin Terkena Dampak Covid-19 Di Desa Talaitad Kecamatan Suluun Tareran Kabupaten Minahasa Selatan.

Chabib Soleh dan Heru Rochmansjah. 2014. Pengelolaan Keuangan Desa. Bandung: Fokusmedia.

Dunn W.N. 2005. Analisis Kebijakan Publik. Yogyakarta: Gadjah Mada University Press.

Emzir. 2010. Metodologi Penelitian Pendidikan Kuantitatif dan Kualitatif. Jakarta: Rajawali Pers.

Fernando, Carly Erfly. 2020. “Efektivitas Bantuan Langsung Tunai Dana Desa Bagi Masyarakat Miskin Terkena Dampak Covid-19 Di Desa Talaitad Kecamatan Suluun Tareran Kabupaten Minahasa Selatan”. Jurnal Politico, Vol.9, No 2.

Halim, Abdul. 2007. Akuntansi Sektor Publik: Akuntansi Keuangan Daerah. Jakarta: Salemba Empat.

Hastuti. 2013. Pemantauan Cepat Bantuan Langsung Sementara Masyarakat (BLSM). Jakarta: Lembaga Penelitian SMERU.

Ima Kumalasari, Slamaet muchsin, Sunariyanto. 2020. Efektivitas Strategi Penanganan Covid-19 Melalui Penerapan Kebijakan Kampung Tangguh Berdasarkan Permendagri No.20 Tahun 2020 Tentang Percepatan Penanganan Covid-19 Di Lingkungan Pemerintah Daerah.

Laksmi, A.C. 2015. Continuing Professional Development for The Auditing Profession: Evidence from Indonesia. RMIT University.

Nordiawan D. 2006. Akuntansi Sektor Publik, Salemba Empat. Jakarta.

Pradana, Irvan Oktariansa. 2021. Alokasi Anggaran Pendapatan dan Belanja Desa (APBDes) pada Masa Pandemi Covid-19 di Kabupaten Lamongan Periode April September 2020 Perspektif Permendes Nomor 7 Tahun 2020. Skripsi: Universitas Islam Negeri Sunan Ampel Surabaya.

Rinda, Nofotna Zalukhu. 2020. Analisis Pengelolaan Anggaran Pendapatan Dan Belanja Desa (Apbdes) Di Desa Lauru I Afulu Kecamatan Afulu Kabupaten Nias Utara.

Supriyono, R.A. 2004. Pengaruh Variabel intervening Kecukupan Anggaran dan Komitmen Organisasi terhadap Hubungan Antara Partisipasi Anggaran dan Kinerja Manajer di Indonesia.

Sugiyono. 2011. Metode Penelitian Pendidikan (Pendekatan Kuantitatif, Kualitatif, Dan R\&D). XIII. Bandung: Alfabeta.

Anonim. 2013. Metode Penelitian Kuantitatif, Kualitatif dan R\&D. Bandung: Alfabeta. 
Umi, Yunianti. 2015. Analisis Efisiensi Dan Efektivitas Anggaran Pendapatan Dan Belanja Desa (APBDesa)

Padk. 2018. Pusat Analisis Determinan Kesehatan. http://www.padk.kemkes.go.id, di unduh 1 November 2020

Undang-Undang Nomor 6 Tahun 2014 tentang Desa.

Permendagri Nomor 20 tahun 2018 Tentang Pengelolaan Keuangan Desa.

Peraturan Menteri Desa, Pembangunan Daerah Tertinggal dan Transmigras Nomor 11 Tahun 2019 Tentang Prioritas Penggunaan Dana Desa Tahun 2020.

Peraturan Menteri Desa, Pembangunan Daerah Tertinggal dan Tranmigrasi Nomor 7 Tahun 2020 Perubahan Kedua Tentang Prioritas Penggunaan Dana Desa Tahun 2020 